\title{
Where is Home for the Abuja, Nigeria Urban Poor?
}

\author{
Obiadi Bons N., Onochie A. O., Nzewi N. U. \\ Department of Architecture, Faculty of Environmental Sciences, \\ Nnamdi Azikiwe University, Awka, Anambra State, Nigeria
}

\begin{abstract}
How to cite this paper: Obiadi Bons N. | Onochie A. O. | Nzewi N. U. "Where is Home for the Abuja, Nigeria Urban Poor?" Published in International Journal of Trend in Scientific Research and Development (ijtsrd), ISSN: 24566470, Volume-3 | Issue-3, April 2019, pp. 45-56. http://www.ijtsrd.co $\mathrm{m} /$ papers/ijtsrd216 56.pdf

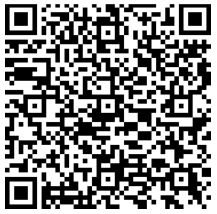
IITSRD21656
\end{abstract}

Copyright (C) 2019 by author(s) and International Journal of Trend in Scientific Research and Development Journal. This is an Open Access article distributed under the terms of the Creative Commons

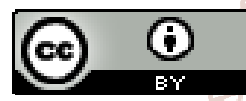
Attribution License (CC BY 4.0) (http://creativecommons.org/licenses/ by/4.0)

\section{INTRODUCTION}

Obiadi (2017), citing Lerner (2003), the city is a fundamental and universal human creation. It is a unique center for social life as well as individual and collective fulfillment. The frantic, irreversible urban growth that societies throughout the world have experienced over the past few decades has caused a transformation of cities and agglomerations, which rarely correspond to inhabitants' legitimate needs, expectations and aspirations.

More than 5,000 years have passed since the Urban Revolution and about 180 generations separate us from the origins of the first cities. But neither the purpose nor the structure of cities has changed basically in the five millennia. What have undergone transformation are the complexity of city life and the size of urban communities. When men first cut out a little space from the surrounding land, enclosed it with a wall, and formed a place where they could live without tilling the soil themselves, they gave up their intimate solidarity with nature. A new type of human being was born and with it, from the very beginning, began the antagonism between the country people and the town people. The first cities were small enclosures with small numbers of inhabitants. They were limited in conception and size and reflected on earth man's vision of a limited universe that, like his city, sheltered him (Okonkwo, 2006).

The first root of urbanization could be located at the point when man's conception of the universe changed from the limited geocentric one to the still limited heliocentric ideas of Copernicus, so over the centuries, the urban scale has widened and the limitations have disappeared. Now that the universe is conceived of as unbounded yet not infinite, something similar has happened to our cities: their scale and their size have grown beyond all expectations into the open country. The old scale has lost its meaning. The first cities arose where and when agriculture was sufficiently advanced to supply food, not alone for the actual producers, but also for those who were not engaged in agriculture. This was the basic prerequisite, for artisans, craftsmen, soldiers, and traders who congregated in the cities. And even if they owned fields outside the city or gardens without it, they produced hardly more than a welcome portion of the food they needed in addition to the supply from full-time farmers (Gutkind, 1964).

In all, the roots of urbanization go deep into human history. The conventional theory was well stated by Mumford (1961). He identified the first germ of the city in the ceremonial meeting place that serves as a goal for pilgrimage, a site to which early man with his family or clan group is drawn back from his wanderings at seasonable

intervals because it concentrates, in addition to any natural advantage it may have, certain spiritual or super national powers. From periodic meetings a few steps lead to settlement and agriculture, to villages and finally, to a differentiation of villages in terms of concentration of technical and religious power, the seats of power becoming 
towns' vis-à-vis the villages. In a counter thesis, Jacobs (1969) advanced the claims of the city above those of the village. She argues that historically it was the development of cities that made possible and necessary the development of satellite agricultural villages; that agriculture was indeed "farmed out" from the city to the countryside.

Whatever its origins and individual peculiarities, an urban center is distinguished most fundamentally by its functions. It is essentially a central place, a center for the mobilization and organization of services for an area. The "basic" urban functions, which generally have to do with administration, commerce, industry, transportation, are facilitated by aggregation. This is in marked contrast to primary production-agriculture, forestry, fishing, mining, extraction and the like - which, spread over favorable sites tied to available sources, is necessarily dispersed (Ukwu, 1980).

Walter Christaller (1966), the pioneer urban theorist whose formulation of the problem remained the most elegant, in modern times, in its logic and simplicity, has likened the process of town formation to "the crystallization" of mass about a nucleus". The number, scale and variety of facilities and services concentrated about a given nucleus determine its status as a town and reflect the size and character of its hinterland.

For a given region, the historical process of urban development does not depend on a steady uni-directional pattern of concentration and coalescence of urban facilities and services about a number of given centers. Rather it hinges on a series of critical events in the socio-economic organization of the communities, events which create new nuclei or enlarge, change the character, diminish or destroy pre-existing ones, hence, the development of towns or systems of towns tends to be episodic and it is often possible to identify the key events and the phases of urban development associated with them.

Each key event imposes a new set of area relationships and a new functional ordering of centers thereby setting the scene for a new phase in urban development. This phenomenon has underscored urban development processes in Nigeria, more than ever since the colonial period (Okonkwo, 1993). The first new towns were created in Nigeria during the colonial period; and they were not created to absorb population over-spill from oversized urban centers, but rather to satisfy the economic and administrative interests of the colonial masters. It was in this way that Enugu and Jos were founded essentially for the exploitation of coal and tin resources, respectively, and Kaduna for administrative convenience (Mabogunje, 1968). Consequently, in its postcolonial period, many urban centers have come into existence while others have received more growth impetus under the political instrument of state and local government area creation, as well as the reallocation and redistribution of resources under the process of socio-economic restructuring in the country. With the relocation of Nigerian capital from Lagos to Abuja, the new capital today stands out as the most important event that is changing hitherto centerto-center relationship in Nigeria.

One way of expressing national goals has been through the establishment of new towns. The two major reasons for these are: one, as capitals for countries which had little urban development or where the colonial capital was poorly placed for national needs, and two, as centers for industry
(Pitte, 1977; Bell, 1981). Historically, Abuja is the viable outcome of an ambitious national dream that is transforming a virgin savannah terrain into the show piece capital of the most populous black nation-Nigeria. Most great cities around the world enjoy a substantial amount of patronage and reputation by virtue of two major factors, among numerous others, namely: "the visual amenity", defined as the general attractiveness of the environment, and "the cultural content" of the city, which is a property of the city capable of projecting significant aspects of the lifestyle of its inhabitants to the international community (Uloko, 2005). As already pointed out earlier, one way of expressing national goals has been through the establishment of new towns; as capitals for countries which had little urban development or where the colonial capital was poorly placed for national needs, and also as centers for industry. Abuja City is a response to these two last reasons.

\section{Lagos as Old Capital of Nigeria:}

City building in Nigeria dates back far into the country's precolonial era. A good number of well-established small towns had formed a strong contrast with then prevailing village types and scattered settlements. But the British bombardment and occupation of Lagos in 1851, in order to put an effective end to the slave trade in that coastal area of the country, marked the beginning of the end of pre-colonial urbanization in Nigeria (Mabogunje, 1968). During the colonial period, a number of factors combined to revolutionize the urban system: establishment of export oriented cash crop economy, development of colonial hierarchy of administrative centers on existing political centers wherever convenient and the creation of new administrative centers in less centralized traditional systems (Okonkwo, 1993).

At the creation of the Southern Nigeria in 1906 Lagos (figure 1.0) was chosen as the capital from among other towns because of its eminent position as a trading town with easy communication with Europe and easy communication with the interior part of the country through the railways which had been commenced from Lagos before the end of the nineteenth century. Another matter which weighed heavily in favour of Lagos was the existence of some rudimentary infrastructure like electricity supply. Even at that time, the possibility of removing the center of administration from Lagos to elsewhere was contemplated and it was thought that in a matter of 10 to 20 years the seat of administration might be moved from Lagos to another town. But it continued in Lagos, even after the amalgamation of the Northern and Southern Nigeria in 1914, in preference to Calabar and Port Harcourt which were also coastal trading towns.

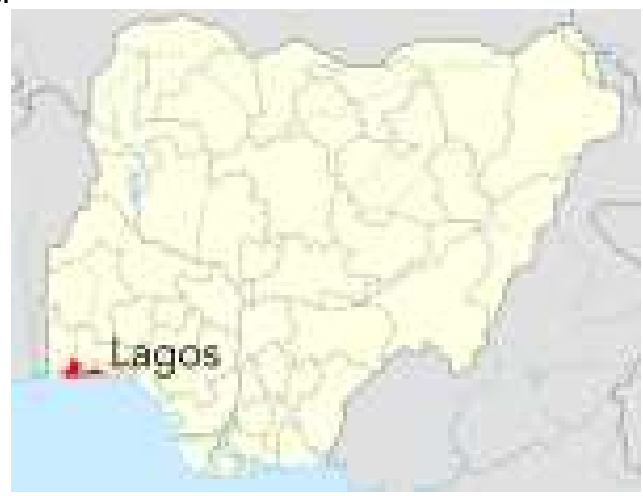

Figure 1.0: Map of Nigeria showing Lagos Source: Emekamozie.worldpress.com 
Thereafter, it continued to be better developed than other towns and cities within the country. It was provided with pipe-borne water in 1915, and was declared a first class township in 1917 and had elected representatives on its council in 1920. In 1923, its existing electric power supply first installed in 1898 was extended. Five years later in 1928, a development board, the Lagos Executive Development Board, was set up with the general duty of planning the city and reclaiming some of the nearby swamps. The administration of the whole country continued there until the 1950's when the likelihood of independence for Nigeria came into sight.

The position of Lagos was one of the most controversial issues among political parties existing in the country before the coming into operation of the 1954 Constitution. In the end, it was the British Government that decided for Nigeria that Lagos should remain the Federal Capital and that the municipal area of Lagos should become Federal Territory and municipal area was excised from the existing Western Region and declared the Federal Territory under the administration of the Federal Government. This position became crystallized under the 1960 Independence Constitution which declared that Nigeria shall consist of three Regions and the Federal Territory was to comprise of the areas which, hitherto, had constituted the Lagos Town Council Area.

\section{Lagos in Conflict:}

Even though the 1963 Republican Constitution did not affect any change in the position, in so far as the Federal Territory was concerned, the actual problem of Lagos as capital of Nigeria began with the coming into effect on May 27, 1967 of the States (Creation and Transitional Provisions) Decree 1967, Decree No. 14 of 1967. That Decree divided the Federation of Nigeria into 12 states, one of which is Lagos State which includes the area previously referred to as the Colony and the then existing Federal Territory. Thus the administration of what had previously been Federal Territory came directly under a State Government, namely, the Lagos State Government. Another significant feature of Decree No. 14 of 1967 is that it added a subsection to section 2 of the 1963 Constitution by which addition Lagos was made the seat of the Federal Government. So, there was no constitutional or statutory provision declaring Lagos as the seat of the Lagos State Government (Okonkwo, 2006).

\section{Federal and State Government Conflicts in Lagos:}

From the foregoing, so long as the administrative functions of both the Federal and State Government are carried out within the same geographical territory of Lagos there was bound to continue to be conflicts. As would be seen, even in some cases where there is legal demarcation as between functions of the two Governments, this did not obviate the occurrence of conflict. As a result, the capability of Lagos to play such dual role diminished considerably. It may be argued that by proper administration this conflict could be totally eliminated but its achievement was reasonably remote as the Government was committed to a federal form of constitution for the country.

\section{The Desire for a New Capital of Nigeria:}

The desire for a new capital of Nigeria was founded on the increasingly diminishing capability of the Lagos territory to cope with the strong expansion of socioeconomic activity which accompanied the oil boom of the 1970s and the unavoidable increase in demand for greater efficiency in administrative management of the country. Within a very short period, within Lagos, land space, physical resources base, and urban infrastructure became inadequate at all levels. Added to these was the fact that the overwhelming majority of Lagos inhabitants were the Yoruba people, one of the major ethnic groups in Nigeria.

So, by a notice dated August 9, 1975, the then Federal Military Government of Nigeria set up a Committee with the following terms of reference:

A. to examine the dual role of Lagos as a Federal and State Capital, and advise on the desirability or otherwise of Lagos retaining that role;

B. in the event of the Committee finding that Lagos was unsuitable for such a role, to recommend which of the two Governments (Federal or State) should move to a new Capital;

C. in the event of the Committee finding that the Federal Capital should move out of Lagos, to recommend suitable alternative locations, having regard to the need for easy accessibility to and from every part of $t$ he Federation;

D. to examine all other relevant factors which will assist the Federal Military Government in arriving at the right decision.

After considering the Committee's report and findings, the need to transfer the capital of Nigeria from Lagos to Abuja (figure 1.1)emerged and as earlier indicated, in May 1967, Lagos became both the Federal Capital of Nigeria as well as the capital of Lagos State with the creation of states and the continued retention of Lagos as the Federal Capital was seriously questioned. The dual role became a source of embarrassing political and administrative complications with the result of that, Lagos became not only unlivable and unserviceable, but also ungovernmeble (Nwafor, 1980, Okonkwo, 2006).

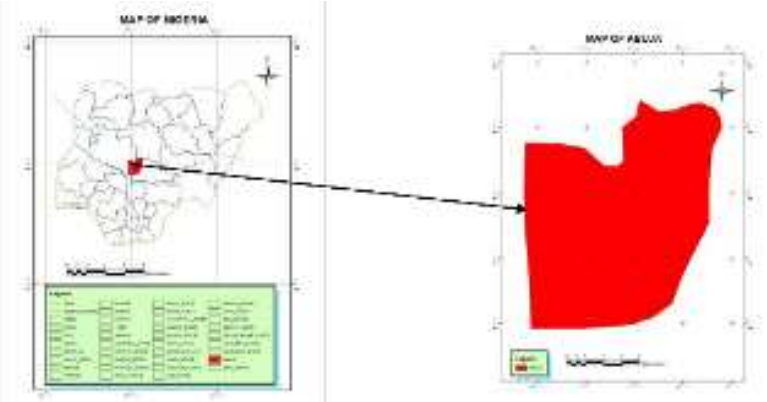

Figure 1.1: Map of Nigeria Showing Abuja Federal Capital Territory

(Source: NARSDA Abuja) (October 22, 2016)

As a result of the peripheral location of Lagos, the city has tended to acquire a regional' rather than a truly national capital where provincialism is stronger than the feeling of the nation's unity. In Nigeria where there is an urgent need to create a national identity and preserve the country as a political unit, the 'created capital' should be so located as to convey a feeling of locational and functional neutrality' (Nwafor (1980), citing Stephenson, 1970, Okonkwo, 2006). In the process, the plan to relocate the capital of Nigeria from Lagos to Abuja (figure 1.2) came in 1975 although, Abuja officially became the capital of Nigeria on 12, December 1991. 
The concept of Abuja as a befitting Federal Capital Territory, centrally located and without the defects of Lagos was spawned in 1975. The site for the Federal Capital City was chosen for its location at the center of the nation, its moderate climate, small population and also for political reasons. To accomplish the goal of relocating the Federal Capital to an area, geographically central to Nigeria and with relative equal accessibility to all parts of the nation, about 845 villages were displaced to make way for the Federal Capital Territory (FCT) (Olaitan, 2004). The Government wanted an area, free of all encumbrances, a principle of "equal citizenship" within the territory where no one can "claim any special privilege of "indigeneity" (figure 1.1) as was the case with Lagos (Jibril, 2006, Okonkwo, 2006). It wanted all the existing population to be moved out of the territory. That was why it authorized not only a census of economic assets of all the inhabitants of the territory but also undertook to pay compensation for all their owners outside of the territory(Jibril, 2006, citing Mabogunje in Ayileka et al, 2001).

In the process of establishing a new nation's capital in Abuja, a Master Plan was developed. The Abuja Master Plan was elaborated to put in place, a sustainable urban spatial environment for all groups or classes of activities to be carried out in the Capital Territory. The development plan and process envisaged the seat of power would move from Lagos to Abuja in 1986, but this time of movement was brought forward to 1982 /83; hence the commencement of urbanization stampeded. The most vulnerable, the urban poor had to arrange, on their own, where to live in order to stay close to work place and also reduce transportation and rent incidence on their income and that resulted in shanty settlements (in both formal and informal housing areas).

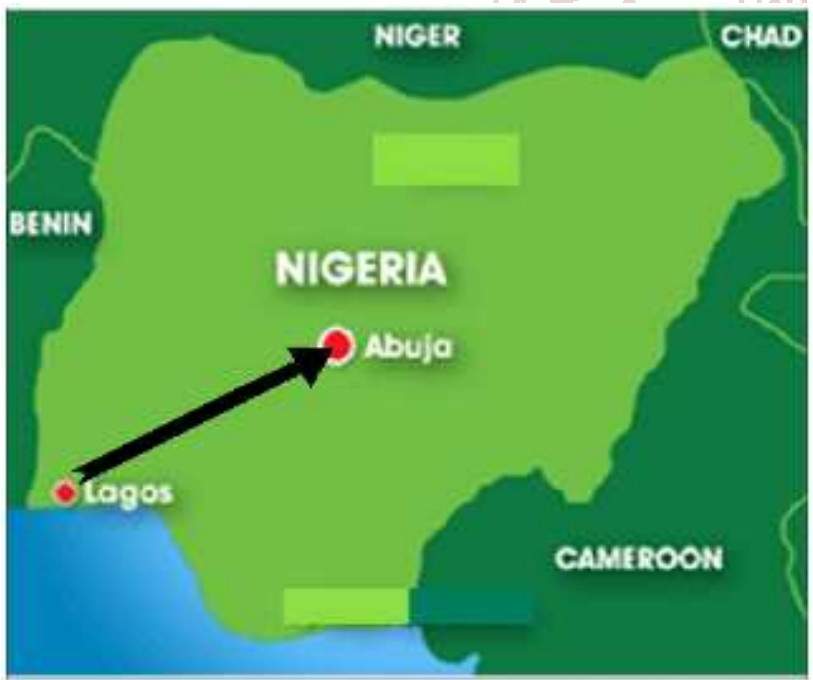

Figure1.2. Nigerian map showing Lagos to Abuja Source: Google map (March, 2015)

The Master Plan was prepared such that land use, infrastructure, housing, transportation, recreation, economic and social services were to be coordinated and inter-related (Olaitan, 2004, citing Abba, 2003). Successive governments (Federal Government and the Federal Capital Territory (FCT) Ministry) in Abuja have neglected these principles (urban development standards). As such, series of distortions to the concept, direction and implementation of the Master Plan are prevalent (Olaitan, 2004).
According to Jibril (2006), "the first major policy statement made by Government in 1976, when it decided to move the Federal Capital of Nigeria from Lagos (in the coastal area) to Abuja (in the central part of the country) was for complete relocation of the entire inhabitants outside the new Federal Capital Territory, of about 8000 square kilometers. This was aimed at freeing the territory from any primordial claims, and to enable the Government to take direct control, plan and develop the new city without any encumbrance, but that was not the case within the governments of Abuja."

According to the Abuja Master Plan (1979), "the development of the city was designed to be in four phases with a clearly defined target population of three million inhabitants. The city was designed as an efficient and attractive environment at each stage of its growth - from Phase 1, which was designed to accommodate 230,000 residents through Phases II and III, which were to accommodate 585,000 and 640,000 respectively, to Phase IV aimed at accommodating 1. 7 million inhabitants (figure 1.3)."Its ultimate population is estimated at 3.1 million (Olaitan, 2004).

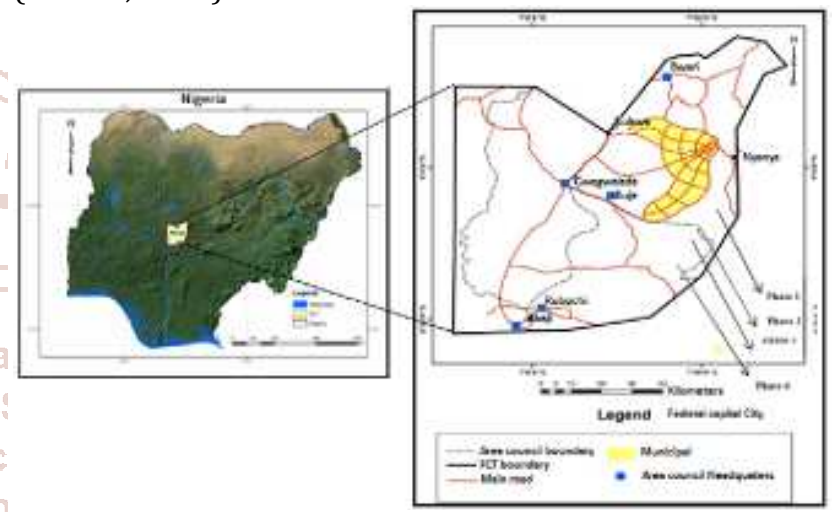

Figure 1.3: Abuja Map and the 4 Phase Development areas Source: ResearchGate (October 22, 2016).

The last known population of the Federal Capital Territory is 2, 440, 200 (population.city, 2016) while the 2016 estimates by T.I.N Magazine (2016), puts the Federal Capital Territory at 3, 100,000 . As it is the case with development implementation in most developing nations, Abuja Master Plan was distorted, following different policy changes that affected the city. According to Jibril (2006), "between 1976 and 2003, (a period of 27 years) there had been about four major policy changes affecting resettlement within the FCT." They are: (1), It was the original intent of the Abuja Master Plan to relocate the inhabitants, occupying the Federal Capital Territory area, however, careful enumeration later revealed that the figure was not 'few' - about 150,000 - 300,000 people. Uprooting such a huge population was thought to be unwise and could have delayed the take-off of the project. It was then decided to allow the inhabitants to remain, but could be resettled within the territory, should their places of abode be affected by city development projects. (2), in some cases, at the time of relocation, plans were canceled for political reasons. While the people affected were fully prepared for movement to the new location, another policy change happened (Jibril, 2006). (3), in preparation for the 2003 general election, the additional security personnel brought into the Federal Capital Territory occupied the buildings under the resettlement scheme(plate 1.0). These major shifts in policy direction can be said to be the root cause of problems of squatters and Land Administration within the FCT (Jibril, 2006). 


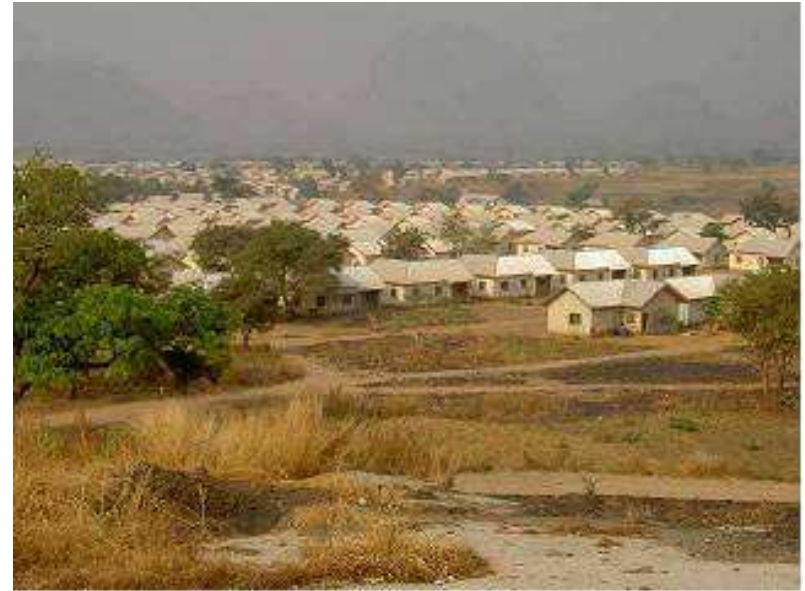

Plate1.0. Resettlement village taken over by the Nigerian Police Force (fieldwork 2005)

Source: Jibril (2006)

(4). The derail and distortion of the Abuja Master Plan was also attributed to lack of professional personnel managing and planning the development of Abuja Master Plan. According to Jibril (2004), "the main cause of the distortions of the Master Plan was the creation of the Ministry of the Federal Capital Territory (MFCT) in 1980 and its being super imposed on the Federal Capital Development Authority (FCDA). The Ministry lacked the professional personnel to understand the philosophy of a Master Plan and the need for detailed planning and design to be carried out before the Master Plan could be transformed into construction activities in any part of the City."Jibril (2006) further indicated that, "in 2003, a Ministerial Committee on Illegal Structures in the FCT was constituted to collate a list of all illegal structures in the FCT and present a strategy for demolition. Interestingly, most of the members of the committee were not professional planners."

(5), the unplanned territorial growth and developments occurring in the Central Area of the City could also be traced back to the governments rush to relocate the government workers from Lagos to Abuja. These problems are as a result of the rushed movement of workers from Lagos to Abuja without adequate provision for accommodation. The result was the emergence of a number of shantytowns and squatter settlements occupied by workers and the growing service population in such places as Karu / Nyanya, Karmo and Gwagwalada because there were not enough housing accommodations in the Central City area of Abuja to house them and the majority of the houses in the Central City were too expensive for the low income workers. These settlements have grown rapidly and are generally unplanned, overcrowded and lacking basic amenities and infrastructure. Although, many of the rushed housing developments within the city area have had to be demolished, the shanty developments persist in the periphery of Abuja especially as there is still little provision for housing accommodation for the low-income workers within the city (Olaitan, 2004).

Adeponle (2013) observed "that Abuja city is growing faster (13\%) than the provisions of its Master Plan." It is fast turning into an environmental embarrassment, with developments springing up in gross isolation of zoning and other planning codes. Abuja, which was supposed to be an epitome of beauty and an enlightened vision of city development, has suffered over the years from unnecessary distortions in the implementation of its Master Plan. (Adeponle, 2013).

As a result of these changes in the Abuja Master Plan and policy inconsistencies, the Abuja Central City designed to be a model city is not sustainable. It is divided between success and failures, rich and poor. It has potentials to flourish, but in most part, impoovished. The Central City is characterized by urban dialectics, dualistic living and infiltration of the formal settlement areas by informal settlers because of provision of services to the inhabitants of the formal settlement areas. There exist, a clear disparity in the socio-economic base of the two settlements yet, they co-exist. The two settlements co-existing within the formal settlement areas of the Central City are not integrated yet, because of nearness to their jobs and survival, the informal settlers infiltrating the formal settlement areas characterized as the urban poor, find their ways into the formal settlement areas of the Central City. In order to provide services and earn their living, the urban poor, through self-efforts, provide their shelters on government vacant lands, abandoned buildings and on city side-walks (plates 1.1 to 1.15).The informal settlement areas within the Central City of Abuja are not integrated into the Central City infrastructure and that is one of the major challenges of the city as a result, promoting urban poor growth that resulted in squatter settlements.

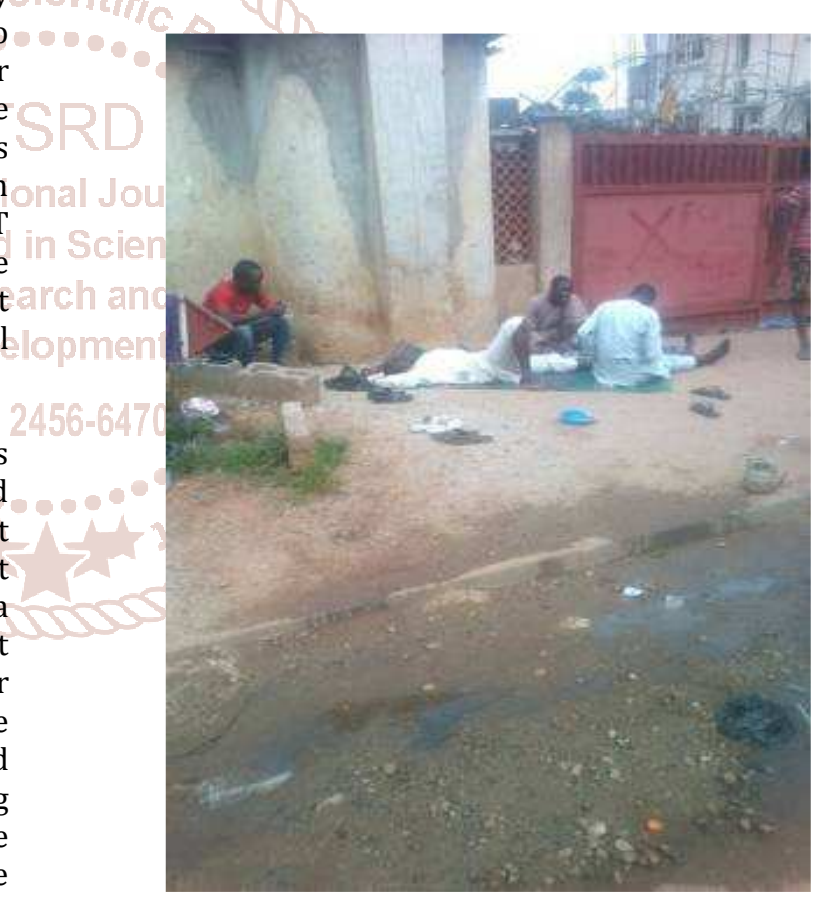

Plate1.1. Abuja's public space (housing/shelter) Source: the author

A typical space becomes the shelter/house and the house becomes the space (for most of these people who are security guards, their relations and friends) in the case of urban poor and urban poor housing in Abuja. In most cases, these spaces are without spatially distributed objects yet, they are side by side with formal settlements without proper links and visually acceptable urban objects, elements and qualities. The nature of the socioeconomic complexity of these informal spaces, which analysis is shown in this work, constitute a strongly identifiable character which is in this work christened Spatial Housing. It is so termed because of the assumption of the public/open space into the provision of the basic (spatial) socioeconomic, psychological, shelter, etc. needs of the urban poor (Obiadi, 2017). 
This phenomenon is different from those of the destitutes/homeless people in the city. The informal inhabitants are more or less fixed in location (even though improper location) and actively dependent on the socioeconomic activities of the urban economy. To that effect, Abuja urbanization is growing more than the area's urban development vis-à-vis housing and economic resources. In the formal sense, spaces can be defined and differentiated, however same cannot be said in the informal, hence 'spatial dialectics'. Within the space is the spatial housing characterized by informal volumetric and unvolumetric combination now called the 'spatial house', 'open house' or 'house without limit (plate 1.1).

\section{All the Abuja government's housing programmes have} failed.

$>$ The housing provided by the Abuja government failed because of inadequacy of housing and a good access to the central facilities through a corridor of open spaces and lack of economic connectivity (secondary employment).

> The Master Plan was prepared such that land use, infrastructure, housing, transportation, recreation, economic and social services were to be coordinated and inter-related (Olaitan, 2004, citing Abba, 2003), but that was not the case during the implementations.

$>$ Much of our daily experience of the city occurs within the collectively shared public spaces, or the public domain. Not only does the public domain provide for most basic of the city's functions, access, but it also provides for and contains many other functions and activities synonymous with urban life. These are lacking and the problem with Abuja's environmental and urban development.

$>$ Prior to 1973, government activities in public housing had been quite sectional and favored only the working class elites in the society. The poor and low-income were relegated to the background (Olu-Sule, 1988).

$>$ The Abuja government's housing programmes have not worked. The provided Federal Housing units were developed without adequate economic and municipal service facilities as a result, the housing units are not sustainable and also, inadequate for the Abuja steaming population. It equally fail because of the government rush to move government workers from Lagos to Abuja when the government has not provided adequate housing for the workers

$>$ Not only that, the Capital City was planned to be built by the Federal Government in its greater part. The Master Plan actually provided for low-income settlements (housing) areas, to be built by the government and to be occupied by the public servants; the private sector servants did not appear to be properly provided for.

The government's approaches to solving the problems of the urban poor housing issues in Abuja Federal Capital Territory have not yielded a reliable solution; especially in the area of urban spatial distribution being created by the invasion of the formal by the informal urban dwellers; and to start solving them, this work explored sustainable spatial integration and retention of the urban poor settlement areas that architecturally bridged the gap (spatial solution) between the urban poor settlements (place of abode) and place of work; thus, evolving a sustainable spatial housing design for the urban poor in Abuja.

\section{Aim of Study}

The present work aims to indicate, that Abuja, Nigeria, has not followed her Master Plan as a result, has not made provisions for adequate housing for the urban poor. The housing interest of the Abuja urban poor has not been clearly established. Abuja been the newest Nigerian city, design to accommodate the interest of all and solve the problems associated with Lagos (the former capital of Nigeria) that resulted on the need for a new capital with equal rights and socio-economic growth as stated on back ground to study, "The desire for a new capital of Nigeria was founded on the increasingly diminishing capability of the Lagos territory to cope with the strong expansion of socioeconomic activity which accompanied the oil boom of the 1970s and the unavoidable increase in demand for greater efficiency in administrative management of the country. Within a very short period, within Lagos, land space, physical resources base, and urban infrastructure became inadequate at all levels." To achieve that, this work investigated the causes of urban poor housing in the Abuja Federal Capital Territory, covering the distortion of the Abuja Master Plan and Abuja urban development process that resulted in shortage of housing for the urban dwellers, development and growth of slums and shantytowns within the Central City (invasion of the formal settlement areas by informal settlers).

\section{Research Methodology}

The authors applied content base analysis (secondary data sources), where they carefully analyzed and interpreted works of other authors and used them in buttressing their points as applied to the issue at hand, "where is home for the Abuja urban poor?" The topical issues of focus are, that the Abuja urban poor has no structured place called home, faced with housing inadequacy, suffers the effects of poor socioeconomic developments or better said, the economic inadequacy and sustainability as a result, authors adopted qualitative research method.

\section{Findings}

Abuja faced the challenges like all the new nation's capital; relocation, resettlement and development. Development was taken to areas which hitherto were not only generally sparsely populated but also contributed quite little to the national economies of each country. The design concept and physical development of the new capitals have been underpinned by the theory and principles of "garden city" by Ebenezer Howard (1898) which influenced the building of Letchworth in 1902 and Welwyn in 1920 as new towns, dealing with urban poverty, inadequacy of housing and spatial integration.

Adiukwu (2014), in his Prospects and Challenges of Informal Settlements and Urban Upgrading in Abuja, indicated that, poverty has a social dimension (poor quality of housing and the living environment, i.e. lack of access to basic services like clean water, health care, education etc.). Abuja is one of the most rapidly urbanizing cities in Africa, faced with challenges of squatter settlers. The shelters are, built by the efforts of the squatters who cannot afford to secure legal or formal land or a safe site on which a house can be built. Informal land developments provide shelter for over $85 \%$ of the population of urban residents in most developing Nations (UNCHS, 1996 and 2000; Durand-Lasserve, 1997).

The government in Abuja has always confused squatter settlements from the urban poor and as Bello (2009) 
indicated, the focus has always been on squatter or informal settlements and not on the urban poor, or their inaccessibility of land. This is a wrong approach. This is why when a squatter settlement is redeveloped, what is successfully done is to push the squatters to another location while redistributing their lands among the rich. Squatter settlements develop because there exits some urban poor who desire at least a roof over their heads, but their income and high cost of land have pushed them to where they are, and called home; and where you called, squatter settlements (Bello, 2009).

Generally, as the population and affluence grew, there exist an increase in the demand for land by government, private individuals and corporate bodies. Unfortunately, since the physical overall supply of land within a geographical area is fixed, demand always outstrips supply by a very wide margin, especially in the urban centers. This inevitably brings about the survival of the fittest syndrome. In this struggle, government has the upper hand through the exercise of the power of eminent domain, while individuals and corporate bodies meet their land requirements in the open markets. Within the open market, the corporate bodies and the rich individuals usually with higher bargaining power, dominate the transaction; while the urban poor are left with little or no choice but to make do with the crumbs. Consequently, this group of individuals, in most cases, occupies the less desirable areas such as marshy sites, neighborhood adjacent to refuse dumps and where they can find one, they encroach on government lands. The emergent settlement usually evolved as a spatial concentration of poor people in the poor areas of the cities. As expected, this settlement is usually characterized by infrastructure deficiencies, shanty structures, poor sanitation, urban violence and crime (plate 1.2). These composition and characteristics have always made squatter settlement a source of worry and concern to the adjacent neighbours and governments (Bello, 2009).

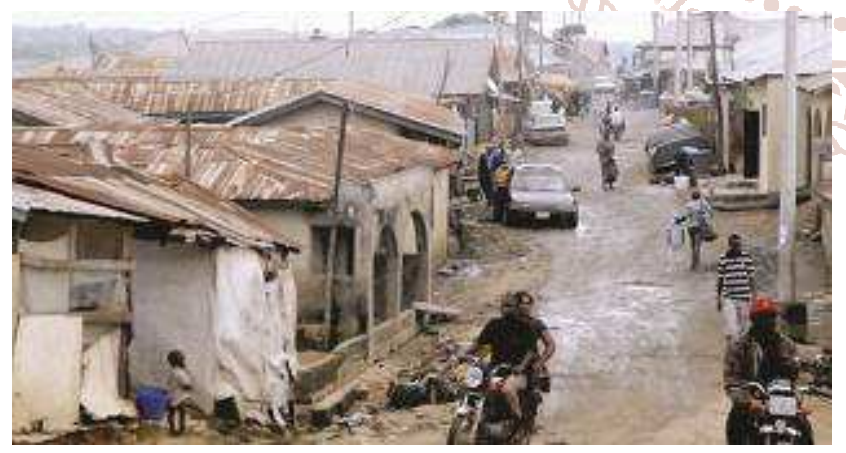

Plate1.2. Typical Abuja Slum Architecture Source: Abuja Metro (2014).

As indicated by Bello (2009), "the harbinger of squatting activities is inaccessibility of land engendered by low income of the urban poor. The end product is the creation of a slum. The effects of slums have been seen from various perspectives; the commonest one being on the deplorable environmental conditions." The slums are occupied by both landlords and tenants.

The tenants include, most of the Central City workers who could not afford high rents within Central City. According to Bamidele (2010), "most of the workers who cannot afford to live within the city, find their way to the squatter settlements and uncompleted or abandoned buildings within the city which punctuated all high-brow areas of the city and many" (plates 1.4 to 1.5). The people, according to Uji and Okonkwo (2007), "frustrated by the inadequacies and failure of the conventional approaches to provide urban shelter and services to a significantly large enough proportion of the poor in the urban areas of the developing nations, these ever-increasing class of urban populations have to resort to squatting on public or private land, either by invading and forcefully occupying or leasing such land (illegally subdivided) on which they hurriedly construct (through selfhelp) their shelters from any available materials using any readily affordable and available technology" as is the case in plates 1.4 to 1.5 found within FCT.

Urban Poverty, according to Adiukwu (2014), citing Copenhagen resolution (2000), "is strongly associated with high levels of environmental risk. This is largely due to poor quality and overcrowded housing conditions and the inadequacies in provision of water, sanitation, drainage, health care, garbage/waste collection, poor percolation resulting into flood, building on waterways and pollution of land, air, and water (plate 1.2 and 1.3). The concentration of more people in urban areas has brought more pressure on the land space for the production of food, infrastructure, housing, and industrialization. The movement affects the capacity of the environment to cope, as each additional person increases the demand on the infrastructure and the natural system and as a result creating ecological imbalance with adverse environmental penalty in hazards and disaster (Daramola and Ibem, 2010).

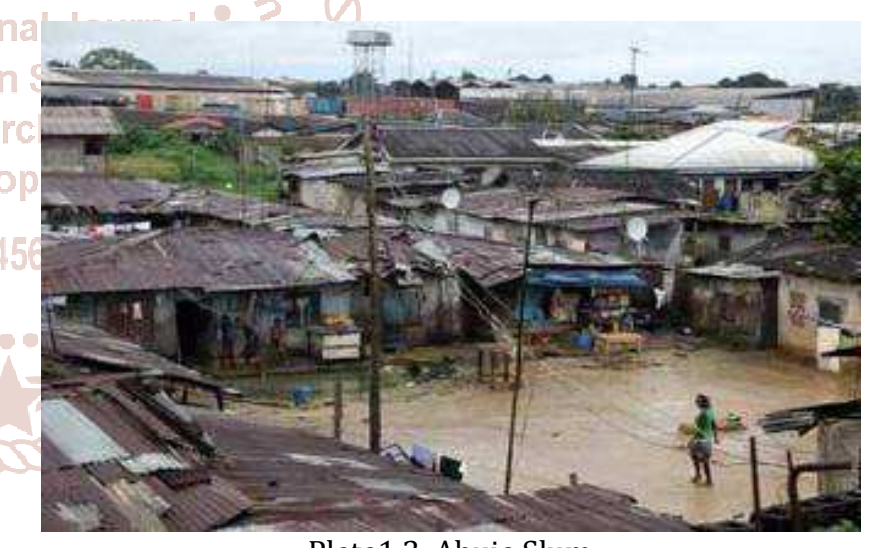

Plate1.3. Abuja Slum

Source: Abuja-ng.com

House: could be defined as a building to live in, especially by one person or family, a house-hold; a family or dynasty including relatives, ancestors and descendants; the audience in a theater, a business firm; a legislative assembly; house music, to provide accommodation or storage for; to cover, encase (Geddess and Grosset, 2005). According to Uji and Okonkwo (2007:17), Turner (1974), sees 'housing' as human dwelling, a roof over one's head meant to serve as shelter for human living, interaction and carrying out of activities away from in clemencies of weather. Uji and Okonkwo (2007) further indicated that, Turner (1974) associates housing with the process of responding to the needs for shelter and the associated demands of social services, health and public facilities which go with the physical shelter in order to ensure congruent living with the environment. Housing generally refers to the social problem of insuring that members of society have a home to live in, whether this is a house, or some other kind of dwelling, lodging, or shelter (Housing, 2013). 
International Journal of Trend in Scientific Research and Development (IJTSRD) @ www.ijtsrd.com eISSN: 2456-6470

\section{Abuja Urban Poor Housing Typology}

The writer's field study photographically documented the current conditions of some of the Abuja urban poor settlements and their characteristics (plates 1.4 to 1.13). It captured the areas' challenges, poor architecture of the unplanned neighborhoods, economic activities, deteriorations in infrastructure, environmental pollution, etc.

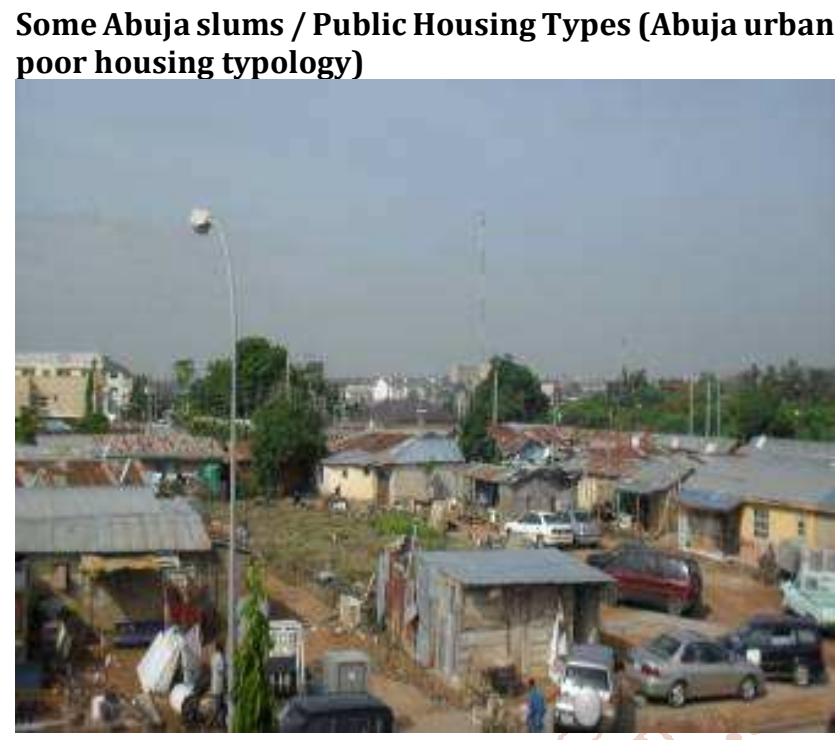

Plate1.4. Utako Settlement area Source: the authors

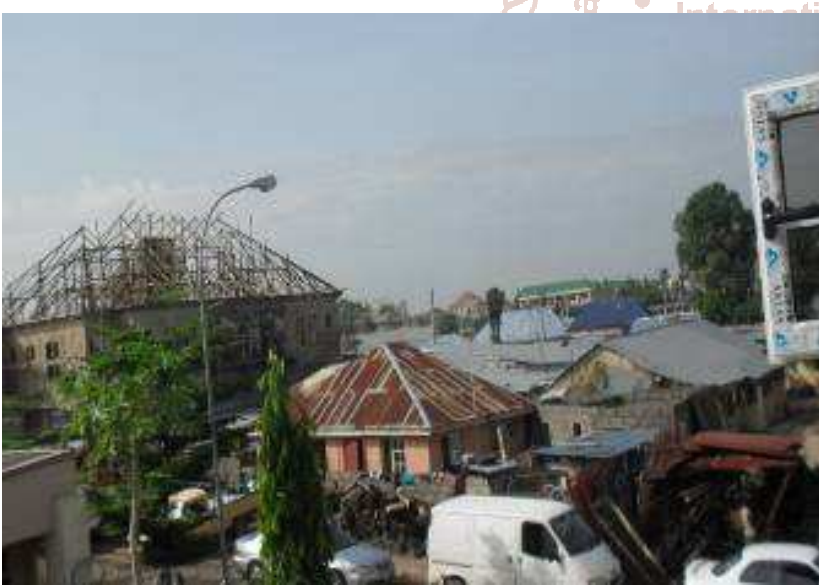

Plate1.5. Utako Settlement area Source: the authors

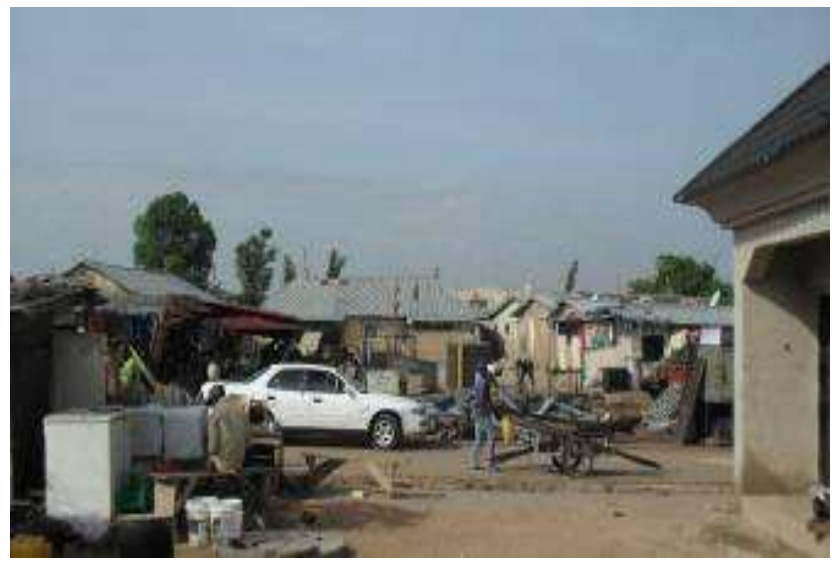

Plate1.6. Utako Settlement area Source: the authors

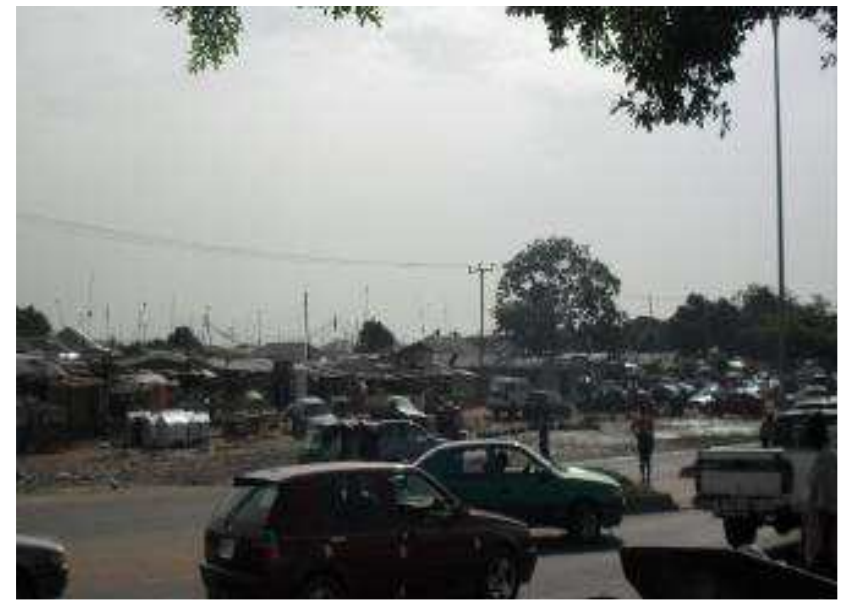

Plate1.7. Utako Settlement area Source: The authors

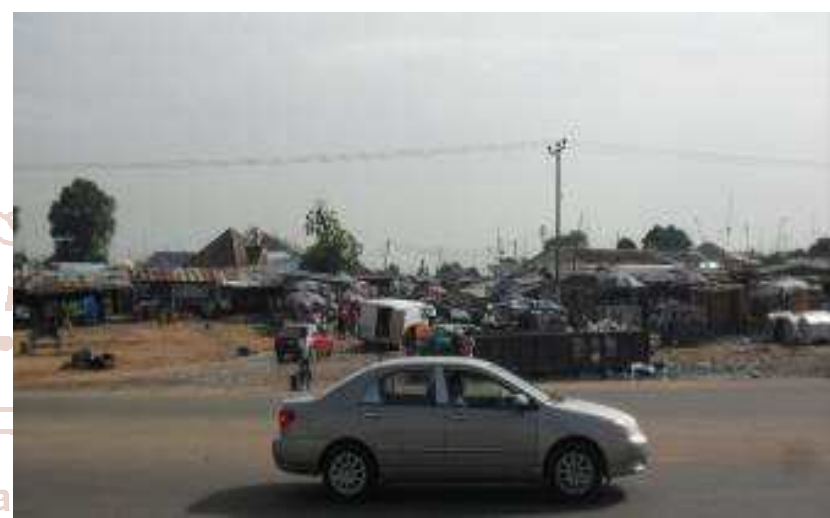

Q Scientific Plate1.8. Utako Settlement area

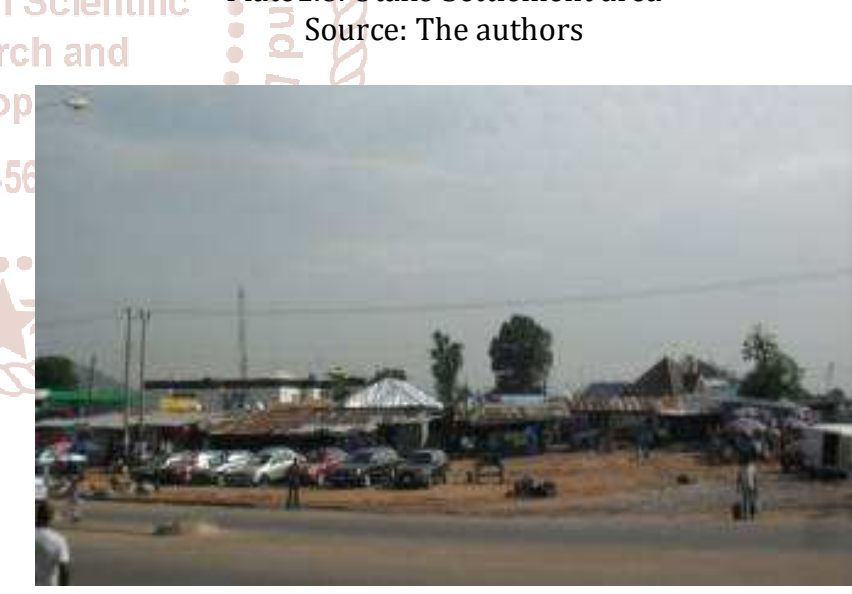

Plate1.9. Utako Settlement area

Source: The authors

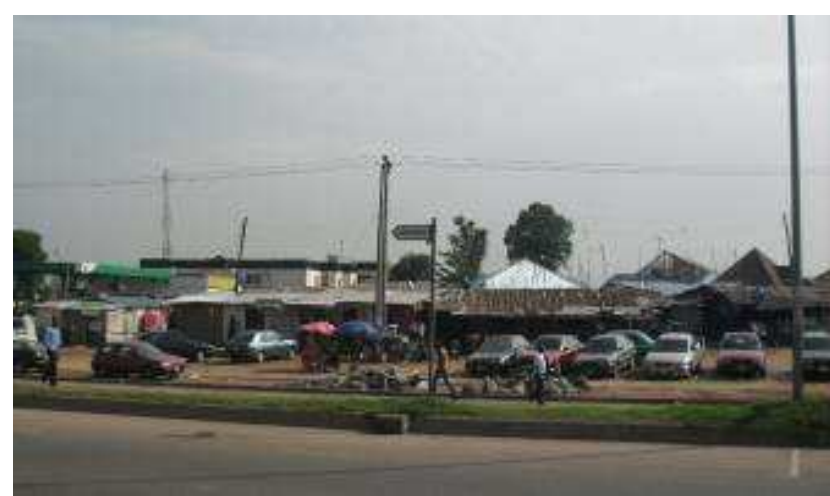

Plate1.10. Jabi Village, ObafemiAwolowo Way Source: the authors 


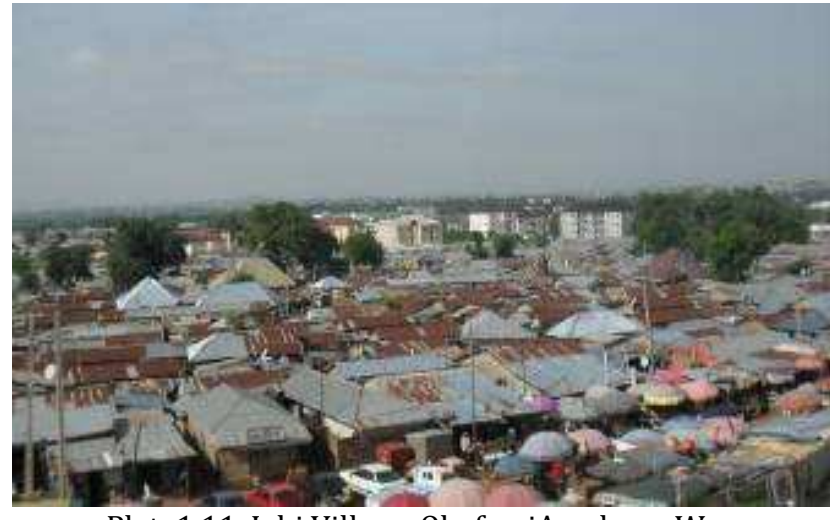

Plate1.11. Jabi Village, ObafemiAwolowo Way Source: the authors

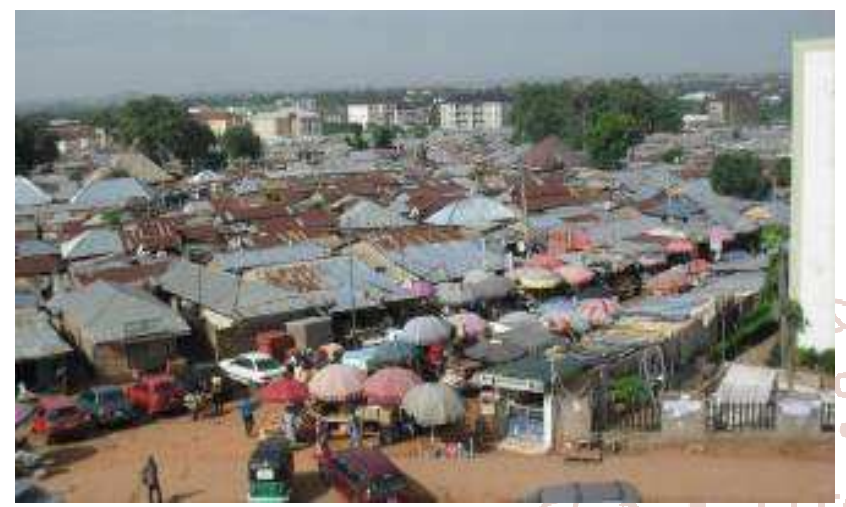

Plate1.12. JabiVllage - I. T. Igbani Street Source: the authors

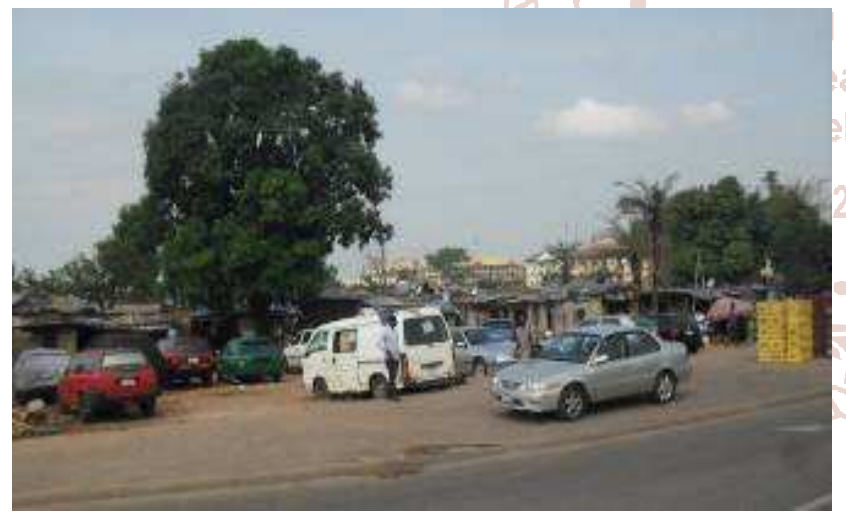

Plate1.13. Utako Village, OkonjoIwulal Way Source: the authors

\section{Statement of Facts:}

$>$ The Abuja Master Plan was elaborated to put in place, a sustainable urban spatial environment for all groups or classes of activities to be carried out in the Capital Territory.

$>$ The Capital City was planned to be built by the Federal Government in its greater part. The Master Plan actually provided for low-income settlements (housing) areas, to be built by the government and to be occupied by the public servants; the private sector servants did not appear to be properly provided for.

$>$ The development plan and process envisaged the seat of power would move from Lagos to Abuja in 1986, but this time of movement was brought forward to 1982/83; hence the commencement of urbanization stampeded. The most vulnerable, the urban poor had to arrange, on their own, where to live in order to stay close to work place and also reduce rent incidence on their income and that resulted in shanty settlements (in both formal and informal housing areas).

This work noted that, the Federal Capital Territory was planned, to be developed in phases and to accommodate the expectant growth and developments. The area demarcated as the FCT is predominantly in Gwariland and falls into one of the very few "buffer" zones. It has displayed a high degree of neutrality between the major northern and southern ethnic groups. The development was planned in such a way that no settlements or people affected would become separated from their "kith and kin" or be rendered "homeless" in the sense that a whole ethnic group may regard themselves "homeless" if their entire land were taken away from them and they were asked to go to settle in lands belonging to other ethnic groups (Okonkwo, 2006).This however, is not the case. A lot of the displaced people of Abuja land found themselves in areas without their "kith and kin" and in most part, rendered "homeless" and living in urban poor settlement areas.

The level of development attention in the Abuja Master's Plan layouts presupposed complete relocation of the villagers to larger villages outside the Capital City; these larger villages formed the basis of the Regional Plan recommendation for development of series of satellite towns to support the Capital City, but that, so far, is not the case. The Central City area is littered with informal settlements in the formal residential areas.

The new capital residential communities are organized around households sharing daily public services which are within walking distances. Such communities vary in size depending on sharing patterns orientation to transportation facilities, residential density, natural physical boundaries, etc. An examination of urban patterns in existing Nigerian cities supports the importance of permitting such factors to reinforce traditional ties of social, cultural, occupational and administrative groupings in evolving a sense of community which can contribute to residential satisfaction. However, the application of this concept in building the new capital implied a physical expunge of the local communities and complete loss of their identity within the city; the names of the villages are retained but the villagers and their settlements are no longer there. Within residential communities, housing dominants land use as well as the most direct point of contact between the new city and its residents. The housing program for the city was formulated to strike a balance between the improved standards of housing which the public and private sectors wished to provide and the costs the city's residents could afford; but seemingly without strategy to involve those who originally inhabited the area because they have been asked to relocate outside the capital city.

Relocation of the local communities was planned in phases and areas. Hitherto Government, under the Federal Capital Ministry, is yet to achieve its relocation plans. Apart from the fact that relocation meant socioeconomic dislocation of the local communities, especially those who fell within the Capital City growth areas, the incomprehensive implementation of the programmes compounded the problems associated with local communities' adjustment in resettlement sites. First-phase relocation involved some 11,000 people while later relocation from the remaining City site involved between 8,500 and 17,000 people. 
However, the associated selective relocation program which meant the relocation of only those villages displaced by specific development has been compounded by constant influx of migrants and steady expansion of the settlements. Nevertheless, while the origin of the problematic situation of the local communities whose settlements fell within the Capital City site could be in the non-implementation of the planned relocation programmes, the problem of those local communities outside the Capital City but within the FCT responds to their seemingly non-inclusion in the spatial economic order which has evolved as a result of the building of the new Capital within their Gwariland (Okonkwo, 2006). The initial Government Policy of housing development through the FCDA made people to expect too much from Government. Even though it wanted to set the pace and encourage people to move into an area that was hitherto least developed in the country and lacking in the most basics of all social amenities. After sufficient confidence was built, government did not see the need to continue with that type of development again and so pulled out in 1991 from large scale housing provisions. It did this at a time when the private sector was yet to produce enough housing stock at affordable rate for the ever growing population of the territory. The consequences are of course acute shortages of housing stock within the city and its immediate environs. The only solution was recourse to squatting solution by people mostly not engaged in the formal sector and therefore not entitled to any form of Government housing provisions. To further compound the problems, the few private developers did not build for low income earners people mostly engaged in the informal sector. Lack of a welldeveloped Mortgage Institutions did not give much room for private developers to provide enough housing scheme for low income earners hence squatter development in Abuja (Jibril, 2006).

Furthermore, there are plans for 150,000 residents by 1986 , largely civil servants from Lagos and their families, and ultimately three million. Residential districts of from 40,000 to 60,000 are grouped into mini-cities of $100,000-250,000$ people with some secondary employment in each. Highdensity areas are placed closer to the transit corridors than low-density areas, but considerable attention has been given to making all sectors of the city easily accessible by motor vehicles. The first housing built was for 20,000 civil servants. As is inevitable in large-scale government projects, there will be far more segregation of housing by income in Abuja than in most Nigerian cities (ECA, 1980).

Based on these conditions, Obiadi (2017), states that the Abuja government has not considered all the housing options, in housing the ever increasing Abuja's population as a result, the Abuja urban poor are found in both formal and informal housing settlements of the city.

\section{Recommendations}

This paper strongly recommends for the Abuja government to review and change her typical ways of implementing government policies. The governments in Nigeria have in the past, developed housing programmes for the urban poor without urban architecture or urban design attributes, contributions of the inhabitants and consideration of their interests and those are, part of the problems with the Nigerian housing delivery programmes and needed to be changed (Obiadi, 2017).
The focal point of this paper was to introduce sustainability (adequacy) of spatial urban development in the Abuja Federal Capital Territory with special attention to the urban poor housing areas retention (shanty, squatter, ghettos, etc.). This paper recommends linking the urban poor settlements areas with the Central City urban economy and improving on their physical or built environment. It recommends retention of the settlements in their current locations. For any reasonable development in the retained settlements, the development must meet engineering and economic feasibilities, physical and biological capabilities, institutional acceptance and endorsement, and political, social, and financial acceptability. They must stand the test of time and have the ability to command resources and compete beyond borders and attract outside influence.

The paper recommends for strict adherence to the goals and objectives of the Master Plan, development laws, the use of professionally trained staff in the execution and implementation of the Master Plan and integration of the informal settlements into the formal settlement areas of the Central City. To promote growth and integration, allocation of Certificate of Occupancy ( $\mathrm{C}$ of $\mathrm{O}$ ) to the residents at the present locations of the settlements is strongly recommended.

\section{Conclusion}

According to Obiadi, (2017), the current Abuja settlement patterns (formal and informal) are not speaking in terms of integration. There is, inexistence, adverse economic inequality and injustice within the Capital City of Abuja and the need for the formal, informal settlements and the Abuja urban actors to be talking, to link the informal and formal settlements together and tie them into the Central City infrastructure. The poor implementation of the Abuja Master Plan, led to dismal miscommunication problems and economic divide within the Abuja Capital City. The city lacked integrity, inclusion of all and shared prosperity. It is a model capital city that lacked inclusive economic growth incentives and not sustainable.

The current situation favors the rich and only through balanced economy can a better society be made of the Abuja Capital City. Share values make for a stronger society. The Abuja urban poor are calling for freedom and dignity by economic integration of the formal and informal settlements. It is understandable that, when your neighbor is successful you want to be successful too. The Abuja Capital City needs to be interconnected with the unstructured segments of the city. The formal and informal settlements of the Abuja Capital City should be talking to each other instead of talking at each other. Abuja's diversity needs to be turned into treasure for the inhabitants, both in the formal and informal settlements (Obiadi, 2017).

As communities try joining the world class, it is important that they direct their attention to the problems of urbanization, homelessness, population and their consequences especially, as they affect human settlements, growth, development and the resources to sustain them. Nigeria Federal Housing Authority indicated the urgent need to provide 12 to 16 million homes in the country (Federal Housing Authority, 2009). 


\section{REFERENCES}

[1] Abba. A (2003) Saving the City of the Abuja from Dir, Faeces, Garbage and Disease. In-depth Analysis Vol 3, N0 5 Nov 2003

[2] Abuja Master Plan (1979). The Master Plan for Abuja. The New Federal Capital of Nigeria.

[3] Federal Capital Development Authority (FCDA), State House, Marina, Lagos, Nigeria.

[4] Adeponle B.J (2013). The Integrated City as a Tool for Sustainable Development. Journal of Educational and Social Research Vol. 3 (5) August 2013

[5] Adiukwu F. O. (2014). Prospects and Challenges of Informal Settlements and Urban Upgrading in Abuja. International Journal of Innovation and Scientific Research ISSN 2351-8014 Vol. 11 No. 2 Nov. 2014, pp. 420-426

[6] Ayileka, O. \&Kalgo, M.S.U(eds.) (2001), The Review of Abuja Master Plan:- Proceedings of an International Workshop for the Review of the Abuja Master Plan, held in Abuja, 9 November - 2 December 1999. Ministry of the Federal Capital Territory, Abuja.

[7] Bamidele Gbemiga (2010) Abuja: The Vexed Problem of Housing, newsdiaryonline.

[8] Bello, Mustapha Oyewole (2009). Squatter Settlement, Accessibility of Land and the Urban Poor. FIG Working Week 2009. Surveyors Key Role in Accelerated Development Eilat, Israel

[9] Bell, M. (1981): "Modern Sector Employment and Urban Social Change: A Case Study from Gaborne, Botswana," Canadian Journal of African Studies, 15, 259-76.

[10] Daramola A and Ibem I (2010): Urban Environmental Problems in Nigeria: Implications For Sustainable Development".

[11] Durand Lasserve (1997). Land for Housing the poor in African cities. Are Neo-Customary

[12] Processes and Effective Alternative to Formal Systems? SEDET Centre National de la Recherche Scientifique Université Denis Diderot, Paris, France. Retrieved from:http://siteresources.worldbank.org/INTURBAND EVELOPMENT/Resources/336387-1268963780932/ 6881414-1268963797099/durand-lasserve.pdf

[13] ECA (1980): Report on the Demographic Survey of Households, Housing and Living Conditions in Lagos, UN Economic Commission for Africa, Addis Ababa

[14] Federal Housing Authority (2009) Public Private Partnership (PPP) Guidelines. Investors' Toolkit, Nigeria. 3-34.

[15] Geddess and Grosset (2005) Webster's Universal English Dictionary, David Dale House, New Lamark, ML11 9DJ, Scotland -p18

[16] Gutkind, E.A. (1964): International History of City Development: Urban Development in Central Europe, Vol. 1, Macmillan, and London.

[17] Housing (2013) Retrieved from: http://en.org/wiki/Housing

[18] Howard, E. (1898): Garden Cities of Tomorrow.
[19] Jacobs, J. (1969): The Economy of Cities, Penguin, London.

[20] Jibril Ibrahim Usman (2006). Resettlement Issues, Squatter Settlements and Problems of Land Administration in Abuja, Nigerian's Federal Capital. Promoting Land Administration and Good Governance, $5^{\text {th }}$ FIG Regional Conference, Accra, Ghana. 1-13.

[21] Lerner, J. (2003): Keynote Address to IUD List of House Types (2013) Retrieved from: http://en.wikipedia.org/wiki/List_of_house_types

[22] Mabogunje, Akin (1968): Urbanization in Nigeria, University of London Press, London, pp.107-108.

[23] Moss Kanter Rosabeth (1995) World Class, Thriving Locally in the Global Economy. Simon and Schuster, Rokyfella Center, 1230 Avenue of the Americas, New York, NY 10020. 19-25.

[24] Mumford, L. (1961): The City in History, University of London Press, London.

[25] Nwafor, J. C., (1980). Department of Geography, University of Nigeria, Nsukka, Nigeria. GeoJournal 4.4 359-336/1980 AkademischeVetlagsgesellschaft, Wiesbaden

[26] Obiadi, B. N. (2017). Evolving Modalities for Sustainable Spatial Housing Design for the Urban Poor in the Federal Capital Territory, Abuja, Nigeria. Department of Architecture, Faculty of Environmental Studies, University of Nigeria, Enugu Campus, Enugu State, Nigeria

[27] Okonkwo Moses M (2006). The Building of a New Capital and its Local Communities: Abuja Federal Capital City in Focus. Public Space as an Element in the Shaping of Local Societes. UrbanistykaMiedzyuczelnianeZeszytyNaukowe NR 11/2006. P68-85

[28] Okonkwo, M.M. (1993): “New Pattern of Development for Cities in Nigeria" Unpublished Ph.D. Dissertation Warsaw, University of Technology, Warsaw, Poland.

[29] Olaitan, DanmoleTaibat (2004). Sustainability and City Development. A Critique of the Implementation of the Abuja Master Plan. Department of Urban and Regional Planning, University of Lagos, Akoka-Yaba, Nigeria.

[30] Olu-Sule, R. A. 1988. Housing and Environmental Planning: A Synopsis on Urban Development in Nigeria. Wusen Press Ltd. 18 EkpoAbasi Street, Calabar. P114115

[31] Pitte, J.R. (1977): Nouakchott: Capitale de la Mauritanie, Dept. de Geographie de L'Universite de Paris - Sorbonne, Paris.

[32] Stephenson, G. V. (1970). Two Newly-Created Capitals: Islamabad and Brasilia. Town Planning Review 41, 317-332

[33] T. I. N Magazine (2016). Most populated Cities in Nigeria, 2016. Retrieved from: takemetonaija.com/2016/05/most-populated-citiesnigeria-2016.html (September 15, 2016)

[34] Turner, J. F. C. (1974). Housing by the People, London: Marion Boyer. Normative and Prescriptive Interactions. Cambridge: university Press. 
International Journal of Trend in Scientific Research and Development (IJTSRD) @ www.ijtsrd.com eISSN: 2456-6470

[35] Uji Zanzan Akaka and Okonkwo Madubueze Moses (2007) Housing the Urban Poor, User Involvement in the Production Process, EDPCA Publications, Enugu, Nigeria, p11-17,

[36] Ukwu, I.U. (1980): "Urbanization and its Implications for the Development of Nigeria", in Readings in Social Sciences, Fourth Dimension Publishers, Enugu. Pp. 167-182.

[37] Uloko, C.O. (2005) "The Abuja Master Plan: The Need for a Better and Sustainable Outlook in International
Circles", in Built Environment Audit, Nigerian Institute of Architects, Lagos.

[38] UNCHS/HABITAT (1996): An Urbanizing World. Global Report on Human Settlements. London: Oxford University Press (for United Nations Centre for Human Settlements).Urban Poverty and Environmental Conditions in Informal Settlements of Ajegunle, Lagos Nigeria836

[39] Walter Christaller (1966). Evaluation of Central Palace Theory. Retrieved

from:

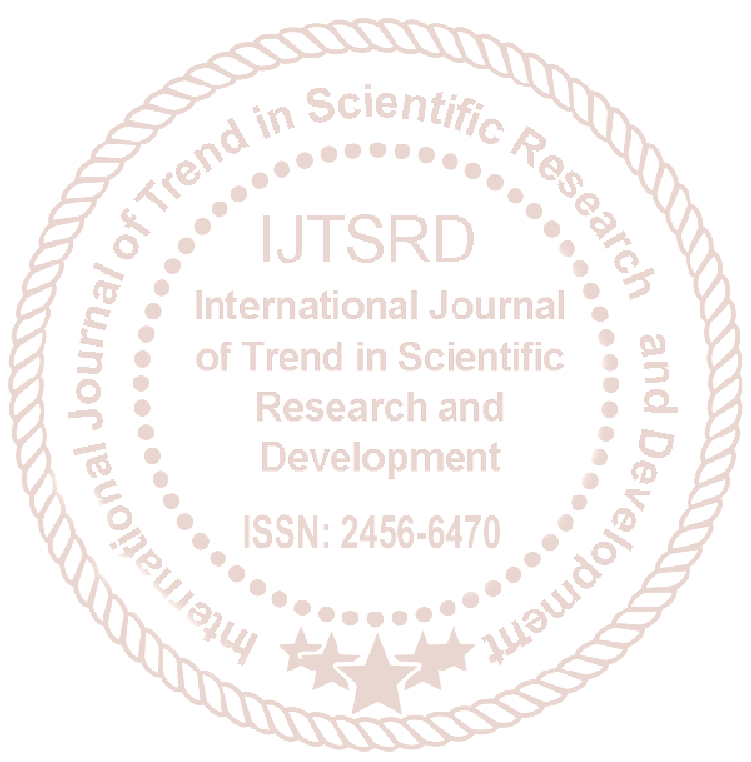

